\title{
Anti-Mac-1 antibodies and early pregnancy loss in mice
}

\author{
S. Savion ${ }^{1}$, J. Irlin ${ }^{2+}$, J. Shepshelovich ${ }^{1}$, M. Brengauz ${ }^{1}$ and V. Toder ${ }^{1}$ \\ ${ }^{1}$ Department of Embryology and Teratology, Sackler School of Medicine, Tel Aviv University, \\ Ramat Aviv, Tel Aviv 69978, Israel; and ${ }^{2}$ Laboratory of Immunology. The Research Institute, \\ Ariel 44820, Israel
}

\begin{abstract}
This study focused on the role of adhesion molecules in early pregnancy in mice. Injection of anti-Mac-I antibodies during early pregnancy resulted in early pregnancy loss (only $30.7 \%$ of mice in the group injected with anti-Mac-1 antibody were pregnant compared with $87.5 \%$ of controls), while mice treated with anti-Mac-I antibodies during late pregnancy did not show a significant abortive effect $(68.8 \%$ mice in the treated group were pregnant compared with $92.9 \%$ of control mice). Anti-LFA-I $\alpha$, LFA-I $\beta$ or mouse Ag-Eb antibodies, when injected during early pregnancy, caused a nonsignificant decrease in pregnancy rate ranging between $15 \%$ and $25 \%(P>0.05)$, while anti-Thy-1.2 antibodies demonstrated a marginal effect only. Staining of uterine tissue sections, collected on days 4-6 of pregnancy, with anti-Mac-1 antibodies, demonstrated antibody bound to cells in the deep endometrium and in the myometrium but not in the uterine area close to the lumen or on the surface of the blastocyst. These results indicate a possible role for the Mac-1 antigen in early pregnancy.
\end{abstract}

\section{Introduction}

Early pregnancy loss occurs quite frequently; however, the reasons for it are usually unclear. It has been estimated that more than $30 \%$ of all known human pregnancy losses may be due to failure of the blastocyst to implant (Toder et al., 1991). The process of implantation in mice involves intensive contact between trophoblast cells and the epithelial surface layer of the endometrium (Denker et al., 1989; Gossler, 1992; Denker, 1993). Although it is generally agreed that such interactions are governed by adhesion mechanisms located at and outside the plasma membrane of the interacting cells, very little is known about the identity of the molecules involved in the process (Hyafil et al., 1981; Denker, 1993). Adhesion molecules are cell surface receptors that are involved in cell-cell, cell-substrate or cell-soluble ligand binding (Springer, 1990; Takeichi, 1990; Hynes, 1992). It has been shown that several adhesion molecules are expressed and appear to play a role in early embryogenesis. These include $\mathrm{E}$ and $\mathrm{P}$ cadherins (Nose and Takeichi, 1986; Vestweber et al., 1987; Ozawa, 1992), integrins of the $\beta_{1}$ and $\beta_{4}$ subfamilies (Ozawa et al., 1985; Denker, 1993) and embigin and neural cell adhesion molecule (N-CAM) of the immunoglobulin superfamily (Huang et al., 1990; Kimber et al., 1994).

Although these data have shed some light on the expression and characterization of various adhesion molecules involved in embryogenesis, no data are available about whether antiadhesion molecule antibodies affect the early stages of embryogenesis in vivo and cause pregnancy loss. Thus, the effects of

${ }^{\dagger}$ Deceased.

Revised manuscript received 7 December 1995. antibodies against various adhesion molecules on the early stages of pregnancy in vivo were investigated, concentrating on adhesion molecules belonging to the leucocyte integrins and immunoglobulin superfamily particularly the Mac- 1 antigen, which is a member of the $\beta_{2}$ family of leucocyte integrins. Mac- 1 is expressed by macrophages and neutrophils, serving as a receptor for the $\mathrm{iC} 3 \mathrm{~b}$ component of complement (Springer, 1990; Hynes, 1992). Both macrophages and neutrophils are known to be present in the mouse uterus during pregnancy and are thought to fulfil multiple immunological and nonimmunological functions, affecting various stages of pregnancy (Finn and Pope, 1991; Stewart and Mitchell, 1991; Orlando-Mathur and Kennedy, 1993; Hunt, 1994). Therefore, any alteration in those functions might disturb the normal course of pregnancy, resulting in pregnancy loss or resorptions. Antibodies against LFA-I and Thy- $I$, which are expressed by leucocytes and $\mathrm{T}$ cells, respectively, and against $\mathrm{Ag}$ - $\mathrm{Eb}$, a new cell surface antigen, which is expressed mainly by nucleated erythrocytes and also by epithelial and endothelial cells in various fetal and adult organs, were also used.

\section{Materials and Methods}

\section{Animals}

Male and female ICR mice (8-12 weeks of age) were purchased from Tel Aviv University and kept under standard conditions. Females were checked for oestrus, caged overnight with males and examined for a vaginal plug on the next morning. The day on which the plug was present was considered as day 1 of pregnancy. 
Table 1. Antibodies used in the study

\begin{tabular}{|c|c|c|c|c|}
\hline Antibody & Clone/Isotope & Family & Expression & Ligand \\
\hline $\begin{array}{l}\text { Thy-1.2 } \\
\text { Thy-1.I }\end{array}$ & $\begin{array}{l}30 \mathrm{H} 12 / \mathrm{IgG}_{2} \mathrm{~b} \\
\mathrm{HO}-22-1 / \mathrm{IgM}\end{array}$ & $\begin{array}{l}\text { Immunoglobulin superfamily } \\
\text { Immunoglobulin superfamily }\end{array}$ & $\begin{array}{l}\text { Lymphocytes } \\
\text { Lymphocytes }\end{array}$ & $\begin{array}{l}\text { Unknown } \\
\text { Unknown }\end{array}$ \\
\hline $\begin{array}{l}\text { Mac-1 } \\
\text { LFA-I } \alpha^{a}\end{array}$ & $\begin{array}{c}\mathrm{M} 1 / 70.15 .11 .5 \cdot \mathrm{HL} / \mathrm{IgG}_{2} \mathrm{~b} \\
\mathrm{M} 17 / 4.4 .11 .9 / \mathrm{lgG}_{2} \mathrm{a}\end{array}$ & $\begin{array}{l}\text { Leucocyte integrins } \\
\text { Leucocyte integrins }\end{array}$ & $\begin{array}{c}\text { Macrophages, neutrophils } \\
\text { Haemopoietic cells }\end{array}$ & $\begin{array}{l}\mathrm{iC} 3 \mathrm{~b} \\
\text { ICAM-1 } \\
\text { ICAM-2 }\end{array}$ \\
\hline LFA-1 $\beta^{a}$ & M18/2.a.12.7//gG $\mathrm{Ia} \mathrm{a}$ & Leucocyte integrins & Haemopoietic cells & $\begin{array}{l}\text { ICAM-1 } \\
\text { ICAM-2 }\end{array}$ \\
\hline $\begin{array}{l}\mathrm{Ag}-\mathrm{Eb} \\
\mathrm{Ag}-\mathrm{Eb}\end{array}$ & $\begin{array}{l}\text { MAE15 (anti-mouse) } / / \operatorname{IgG} \\
\text { HAE9 (anti-human) }{ }^{c} / \operatorname{lgM}\end{array}$ & $\begin{array}{l}\text { Unknown } \\
\text { Unknown }\end{array}$ & $\begin{array}{l}\text { Nucleated erythroid cells } \\
\text { epithelial cells, } \\
\text { endothelial cells }\end{array}$ & $\begin{array}{l}\text { Unknown } \\
\text { Unknown }\end{array}$ \\
\hline
\end{tabular}

${ }^{a}$ Kind gift from N. Hollander (Department of Human Microbiology, Tel Aviv University). 'levleva et al., 1976. 'Mechetner et al., 1987.

\section{Reagents}

Rosewell Park Memorial Institute-1640 (RPMI-1640), penicillin, streptomycin, fungizone, fetal calf serum (FCS), L-glutamine, sodium pyruvate and nonessential amino acids (NEAA) were purchased from Biological Industries (Beth Haemek). 2-Mercaptoethanol (2-ME) and sodium azide $\left(\mathrm{NaN}_{3}\right)$ were purchased from Fluka (Buch) and BSA, glycerol-gelatin solution, casein, 3-aminopropyltriethoxysilane and diaminobenzidine (DAB) were purchased from Sigma (St Louis, MO). Paraformaldehyde and hydrogen peroxide $\left(\mathrm{H}_{2} \mathrm{O}_{2}\right)$ were purchased from Merck (Darmstadt) and streptavidin-conjugated horseradish peroxidase (HRP) was from Zymed Laboratories (San Francisco, CA). Tissue culture supplies were from Greiner (Murtingen), except for tubes for fluorescence activated cell sorter (FACS) analysis which were from Sarstedt (Numbrecht).

\section{Antibodies}

The antibodies against adhesion molecules used throughout the study are listed in Table 1. All antibodies were used as rat or mouse hybridoma cell line supernatants. The amount of the antibodies in the supernatants was detected by the ELISA technique, using enzyme-conjugated antibodies to the various isotypes of immunoglobulins used. In some experiments commercial anti-Mac-I antibodies (rat anti-mouse Mac-I; clone $\mathrm{M}_{1} / 70, \operatorname{lgG}_{2} b$; Pharmingen, San Diego, CA) were used for comparison. Both the hybridoma supernatants and the commercial antibody were used at a dose of $20 \mu \mathrm{g}$ per mouse and the results obtained were similar in both cases. Biotinconjugated mouse anti-rat IgG (Fab fragment) was purchased from Jackson Immunoresearch Laboratories (West Grove, PA).

\section{Treatment of mice with anti-adhesion molecule antibodies}

Mice were injected i.p. ( $1 \mathrm{ml}$ per mouse) with the antibodies listed in Table 1 or with complete medium used for the growth of the hybridoma cell lines (PRMI-1640 supplemented with $100 \mathrm{iu}$ penicillin $\mathrm{ml}^{-1}, 100 \mu \mathrm{g}$ streptomycin $\mathrm{ml}^{-1}, 0.25 \mu \mathrm{g}$ fungizone $\mathrm{ml}^{-1}, 1 \mathrm{mmol}$ L-glutamine $\mathrm{l}^{-1}, 1 \mathrm{mmol}$ sodium

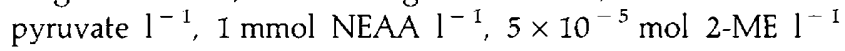

and $10 \%(\mathrm{v} / \mathrm{v}) \mathrm{FCS})$. Three injections of the antibodies were given either early in pregnancy (before implantation, days 2-5) or during late pregnancy (days 7-11). The experiments were terminated on day 13-14 of pregnancy and the number of implantation sites and the percentage of postimplantation loss were calculated; the masses of embryos and placentae were determined and embryos were examined for malformations.

\section{Immunohistochemistry}

Uteri collected from animals treated with anti-Mac-1 antibodies or complete medium were snap-frozen in liquid nitrogen. The samples were cut into 5-7 $\mu \mathrm{m}$ thick sections, layered on pretreated 3-aminopropyltriethoxysilane slides and fixed in $2 \%(\mathrm{w} / \mathrm{v})$ paraformaldehyde in PBS for $15 \mathrm{~min}$ at $4^{\circ} \mathrm{C}$. After prolonged washing in tap water, the sections were incubated with $0.3 \%(\mathrm{v} / \mathrm{v}) \mathrm{H}_{2} \mathrm{O}_{2}$ in PBS for 15 min to block endogenous peroxidase activity. The sections were then washed in $0.5 \%$ $(\mathrm{w} / \mathrm{v})$ casein and $0.1 \%(\mathrm{w} / \mathrm{v}) \mathrm{NaN}_{3}$ in PBS twice for $5 \mathrm{~min}$ and treated for 20 min with FCS diluted 1:5. The excess of serum was shaken off without washing and the slides were incubated with the anti-Mac-1 antibody for $50 \mathrm{~min}$ at room temperature in a humid chamber. After four washes of $5 \mathrm{~min}$ duration in the casein/ $/ \mathrm{NaN}_{3} / \mathrm{PBS}$ solution, the sections were incubated with biotin-conjugated mouse anti-rat $\operatorname{IgG}\left(2.5 \mu \mathrm{g} \mathrm{ml}^{-1}\right)$ for $50 \mathrm{~min}$ at room temperature in a humid chamber. After another wash as described above, the sections were incubated with streptavidin-conjugated HRP $\left(10 \mu \mathrm{g} \mathrm{ml}^{-1}\right)$ for $20 \mathrm{~min}$ at room temperature, washed again and developed with $0.2 \mathrm{mg} \mathrm{DAB}$ $\mathrm{ml}^{-1}$ and $0.05 \%(\mathrm{v} / \mathrm{v}) \mathrm{H}_{2} \mathrm{O}_{2}$ in PBS (20 min, in the dark). The sections were washed well in tap water and the signal enhanced by incubation in $8 \%(\mathrm{w} / \mathrm{v}) \mathrm{CuSO}_{4}$ (for $20 \mathrm{~min}$ at room temperature). After another wash in tap water, the sections were counterstained with haematoxylin and covered with coverslips using a glycerol-gelatin solution.

\section{Statistical analysis}

Statistical analysis of the data was performed by Student's $t$ test. Significance was considered at the $P<0.05$ level. 
Table 2. Abortifacient effect of anti-Mac-1 antibodies in mice

Proportion mice pregnant after treatment (\%)

\begin{tabular}{|c|c|c|c|c|c|c|c|c|}
\hline $\begin{array}{l}\text { Stage of } \\
\text { pregnancy }\end{array}$ & $\begin{array}{l}\text { Control } \\
\text { complete } \\
\text { medium }\end{array}$ & $\begin{array}{l}\text { Anti- } \\
\text { Mac-1 }\end{array}$ & $\begin{array}{c}\text { Anti- } \\
\text { Thy-1.2 }\end{array}$ & $\begin{array}{l}\text { Anti- } \\
\text { LFA-I } \alpha\end{array}$ & $\begin{array}{l}\text { Anti- } \\
\text { LFA-I }\end{array}$ & $\begin{array}{l}\text { Anti- } \\
\text { mouse } \\
\text { Ag-Eb }\end{array}$ & $\begin{array}{c}\text { Anti- } \\
\text { Thy-1.1 }\end{array}$ & $\begin{array}{l}\text { Anti- } \\
\text { human } \\
\mathrm{Ag}-\mathrm{Eb}\end{array}$ \\
\hline Early & $\begin{array}{l}77 / 88 \\
(87.5)\end{array}$ & $\begin{array}{c}18 / 59 \\
\left(30.7^{*}\right)\end{array}$ & $\begin{array}{l}39 / 48 \\
(81.3)\end{array}$ & $\begin{array}{l}14 / 23 \\
(60.9)\end{array}$ & $\begin{array}{l}14 / 20 \\
(70.0)\end{array}$ & $\begin{array}{l}11 / 15 \\
(73.3)\end{array}$ & $\begin{array}{c}7 / 7 \\
(100)\end{array}$ & $\begin{array}{l}13 / 15 \\
(86.6)\end{array}$ \\
\hline Late & $\begin{array}{l}14 / 15 \\
(92.9)\end{array}$ & $\begin{array}{l}11 / 16 \\
(68.8)\end{array}$ & - & - & - & - & - & - \\
\hline
\end{tabular}

${ }^{*} P<0.001$

Table 3. Pregnancy characterization after treatment with anti-Mac-1 antibody

\begin{tabular}{lcc}
\hline & $\begin{array}{c}\text { Control } \\
\text { complete } \\
\text { medium }\end{array}$ & $\begin{array}{c}\text { Anti-Mac-I } \\
\text { antibody }\end{array}$ \\
Parameter & $11.7 \pm 2.1$ & $10.2 \pm 2.8$ \\
\hline $\begin{array}{c}\text { Number of implantation sites per mouse } \\
\quad \text { (mean } \pm \mathrm{SD} \text { ) }\end{array}$ & 5.4 & 4.6 \\
Post-implantation loss (\%) & $0.82 \pm 0.08$ & $0.78 \pm 0.12$ \\
Embryo mass $(\mathrm{g})$ (mean $\pm \mathrm{SD})$ & $0.11 \pm 0.01$ & $0.10 \pm 0.01$ \\
Placenta mass $(\mathrm{g})$ (mean $\pm \mathrm{SD})$ & &
\end{tabular}

${ }^{\text {aT }}$ The percentage of postimplantation loss was calculated from the total number of implantation sites in each experimental group.

\section{Results}

Only the anti-Mac-I antibody, when injected during early pregnancy, caused a significant reduction (up to $60 \%$ ) in the percentage of pregnant mice (Table 2). When injected during late pregnancy, anti-Mac-I antibody reduced the pregnancy rate by about $20 \%$ only. Anti-LFA-1 $\alpha$, LFA-1 $\beta$ and mouse $\mathrm{Ag}$-Eb antibodies, when injected during early pregnancy, caused a nonsignificant $15-25 \%$ reduction in pregnancy rate, while anti-Thy- 1.2 antibodies, which are isotype-matched with anti-Mac-1 antibodies, demonstrated a marginal effect only. The effects of anti-Thy-I.I and human Ag-Eb antibodies on pregnancy rate were similar to that of complete medium. Various pregnancy parameters, including the number of implantation sites per mouse, the percentage of postimplantation loss and the masses of embryos and placentae were not affected by the anti-Mac- 1 antibody (Table 3), emphasizing its significant effect on pregnancy rate only. The antibody-binding cells were localized in vivo by collecting uterine tissue sections on days 4-6 of pregnancy and staining them with the anti-Mac-1 antibody. Figure 1a demonstrates a blastocyst in the uterine lumen, with no stained cells on its surface or in the uterine area close to the lumen. Some Mac-1-positive cells were found scattered around the endometrium, while most stained cells were located in the deep endometrium adjacent to the myometrium and in the myometrium itself (Fig. 1b).
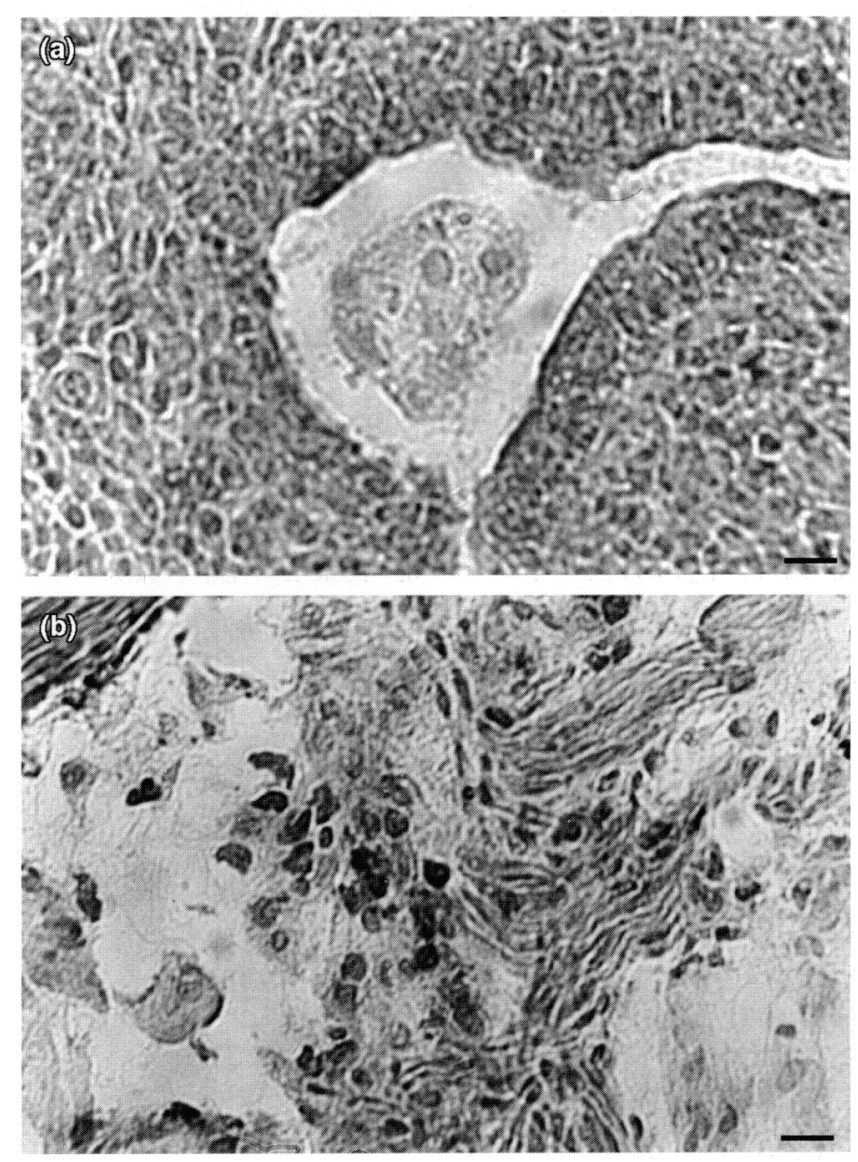

Fig. 1. Uterine tissue sections collected on day 4 of pregnancy, stained with anti-Mac-1 antibodies, followed by streptavidinconjugated horseradish peroxidase. (a) Blastocyst in the uterine lumen, with no anti-Mac-1 antibody-bound cells in its proximity. (b) Antibody-bound cells located in the myometrium. Scale bars represent $100 \mu \mathrm{m}$.

\section{Discussion}

The present study examined the effect of antibodies against various adhesion molecules on the early stages of pregnancy, as reflected by changes in pregnancy outcome. To the best of our knowledge, this is the first demonstration of a significant reduction in the percentage of pregnant mice after anti-Mac-1 
antibody injection during early but not late pregnancy. Since the antibody did not cause postimplantation loss, and had no effect on other pregnancy parameters, it is probable that it interferes with the preimplantation stages of embryo development or with the implantation process itself. The ability of antibodies administered to animals in vivo to reach their target organ and exert their effect has been demonstrated by Athanassakis et al. (1987), who showed that anti-T-cell antibodies can affect various placental cell functions, when administered in vivo to pregnant animals. Examination of uterine tissue sections collected on days 4-6 of pregnancy demonstrated the presence of numerous anti-Mac- 1 antibody-stained cells in the deep endometrium adjacent to the myometrium and in the myometrium itself but not anywhere near the uterine lumen, where the blastocyst starts to implant. The results presented here are in agreement with the observations of Hunt (1994) and Rogers et al. (1992) concerning the redistribution of uterine macrophages and neutrophils, respectively, during implantation. Thus, on the basis of the immunohistochemistry data, the anti-Mac-I antibody can be assumed to affect the implantation process indirectly by interfering with the normal activities of uterine Mac-1-positive cells, during early pregnancy. In addition, the possibility of some systemic effect triggered by the antibody cannot be excluded. Since Mac-Ipositive cells (mostly macrophages) are known to be a major source of cytokines that affect various stages of pregnancy, it is possible that not only uterine macrophages but also para-aortic lymph node or spleen-derived macrophages may participate in this process.

In conclusion, the results reported here demonstrating the ability of anti-Mac-I antibodies to cause pregnancy loss in vivo re-emphasize the role of adhesion molecules in regulating complex morphological events in the early stages of pregnancy.

This work was partially supported by a grant from the United States-Israel Binational Science Foundation and by The Israel Academy of Sciences and Humanities. The secretarial help of O. Lachover is highly appreciated.

\section{References}

Athanassakis I, Bleackley RC, Paetkau V, Guilbert L, Barr PJ and Wegmann TG (1987) The immunostimulatory effect of $T$ cells and $T$ cell lymphokines on murine fetally derived placental cells Journal of Immunology 138 37-44

Denker HW (1993) Implantation: a cell biological paradox Journal of Experimental Zoology 266 541-558
Denker HW, Hohn HP and Bukers A (1989) Investigations on the cell biology of embryo implantation. In Reproductive Biology and Medicine pp 224-238 Eds AP Holstein, KD Voigt and D Grasslin. Diesbach Verlag, Berlin

Finn CA and Pope MD (1991) Infiltration of neutrophil polymorphonuclear leucocytes into the endometrial stroma at the time of implantation of ova and the initiation of the oil decidual cell reaction in mice Journal of Reproduction and Fertility 91 365-369

Gossler A (1992) Early mouse development. In Early Embryonic Development of Animals pp 151-201 Ed. W Henning. Springer-Verlag, Berlin-Heidelberg

Huang RP, Ozawa M, Kadomatsu K and Muramatsu T (1990) Developmentally regulated expression of embigin, a member of the immunoglobulin superfamily found in embryonal carcinoma cells Differentiation 45 76-83

Hunt JS (1994) Immunologically relevant cells in the uterus Biology of Reproduction 50 461-466

Hyafil F, Babinet C and Jacob F (1981) Cell-cell interactions in early embryogenesis: a molecular approach to the role of calcium Cell 26 447-454

Hynes RO (1992) Integrins: versatility, modulation, and signaling in cell adhesion Cell 69 11-25

levleva ES, Engelhardt NV and Abelev GI (1976) Specific antigen of murine erythroblasts International Journal of Cancer 17 798-805

Kimber SJ, Bentley J, Ciemerych M, Moller CJ and Bock E (1994) Expression of N-CAM in fertilized pre- and perimplantation and parthenogenetically activated mouse embryos European Journal of Cell Biology 63 102-113

Mechetner EB, Tonevitsky AG, levleva ES, Rozinova EN and Popova ON (1987) Identification of a human erythroid cell surface antigen Experimental Hematology 15 355-359

Nose A and Takeichi M (1986) A novel cadherin cell adhesion molecule: its expression patterns associated with implantation and organogenesis of mouse embryos Journal of Cell Biology 103 2649-2658

Orlando-Mathur CE and Kennedy TG (1993) An investigation into the role of neutrophils in decidualization and early pregnancy in the rat Biology of Reproduction 48 1258-1265

Ozawa M (1992) Cell adhesion molecules expressed on early embryonic cells Proceedings of the 7th Annual Meeting of the Japan Society for Immunology of Reproduction pp 56-64 Ed. Y Nagata. Japan Society for Immunology of Reproduction, Kagoshima

Ozawa M, Sato M, Muramatsu H, Hamada H and Muramatsu T (1985) A membrane glycoprotein involved in teratocarcinoma cell adhesion to substratum Experimental Cell Research 158 127-143

Rogers PAW, Macpherson AM and Beaton L (1992) Reduction in endometrial neutrophils in proximity to implanting rat blastocysts Journal of Reproduction and Fertility $96283-288$

Springer TA (1990) Adhesion receptors of the immune system Nature 346 $425-434$

Stewart IJ and Mitchell BS (1991) The distribution of uterine macrophages in virgin and early pregnant mice Journal of Anatomy 179 183-196

Takeichi M (1990) Cadherins: a molecular family important in selective cell-cell adhesion Annual Reviews of Biochemistry 59 237-252

Toder V, Strassburger D, Carp H and Irlin J (1991) Mouse model for the treatment of immune pregnancy loss American Journal of Reproductive Immunology $26 \quad 42-46$

Vestweber D, Gossler A, Boller K and Kemler R (1987) Expression and distribution of cell adhesion molecule uvomorulin in mouse preimplantation embryos Developmental Biology 124 451-456 